This is the Author's Accepted Manuscript version, uploaded in accordance with the publisher's self-archiving policy. Please note: this is the author's version of a work that was accepted for publication in DESALINATION. Changes resulting from the publishing process, such as editing, structural formatting, and other quality control mechanisms may not be reflected in this document. The definitive version is available at: $\underline{\text { http://dx.doi.org/10.1016/i.desal.2008.03.053 }}$ 


\title{
Water level fluctuations in a coastal lagoon: El Yali Ramsar wetland, Chile
}

\author{
Alejandro Dussaillant ${ }^{\mathrm{a}^{*}}$, Pablo Galdames ${ }^{\mathrm{b}}$, Chi-Le Sun ${ }^{\mathrm{b}}$ \\ ${ }^{a}$ Department of Civil Engineering \& EULA Environmental Center, Universidad de Concepción, Chile \\ Tel.+56-41-2204320; email: ale.dussaillant@gmail.com \\ ${ }^{b}$ Department of Civil \& Environmental Engineering, Pontificia Universidad Católica, Chile
}

\begin{abstract}
El Yali coastal reserve is the most important wetland complex in central Mediterraneanclimate Chile, especially due to the native and foreign bird fauna which arrives here periodically; the wetlands represent habitat for more than $25 \%$ of the bird biodiversity in Chile. The coastal lagoon, part of a micro-tidal estuary (1.2 m tidal range), is a shallow ( $<1 \mathrm{~m} \mathrm{depth})$ dynamic system and unique site of coexistence of northern halophyte and southern palustrian riparian vegetation. This study identifies and quantifies the effect of forcing variables in the lagoon's water level over one year of data collection. Transects of piezometers with level sensors were installed between the coastal lagoon and the sea. Monthly water quality data were collected. The soil is sandy with porosity of 0.43 and hydraulic conductivities circa $10^{-4} \mathrm{~m} \mathrm{~s}^{-1}$. During the winter rainy season, the lagoon connects with the sea via an ephemeral tidal inlet, producing noticeable daily variations in the water level, up to $80 \mathrm{~cm}$ depending on the tides. In contrast, during the season when bar closure of the inlet disconnects the lagoon from the sea, the lagoon level is very stable, and only decreases very slowly due to evaporation, which also makes the system hypersaline. Rainfall does not affect the lagoon level considerably, although groundwater levels responded quickly as expected for the sand berm material. During the connection phase, analyses using general pattern, spectral and Fourier analysis of the sea vs. lagoon-level signals show that two temporal scale hierarchies are relevant: monthly (due to moon cycles) and daily (due to tidal cycles every 12.5 and $24.2 \mathrm{hrs}$ ). A simple diffusion numerical model simulated the water table trends well for the sand bar between lagoon and sea, supporting the main effect of sea level on lagoon water levels. These and other methods coupled with ongoing data collection and the augmented monitoring network are to be used soon in connection to vegetation spatial data to study water-level and riparian vegetation interactions.
\end{abstract}

Keywords: Coastal lagoon; Groundwater; Semi arid area; Riparian; Eutrophication, Fourier.

*Corresponding author. 


\section{Introduction}

Wetlands are considered among the most productive ecosystems and key service providers to humankind $[1,2,3,4,5,6,7,8]$. Coastal lagoons in particular, being in the boundary or ecotone between land and sea, are delicate and dynamic ecosystems, exposed to frequent fluctuations and alterations. Hydrodynamic processes include forcings by meteorology, tides, winds and spatial/temporal variability of salinity and temperature $[1,5,6,7,8]$. In a coastal lagoon, the spatial distribution of salinity usually affects biota and hydraulics of the wetland. On the other hand, halophyte vegetation stabilizes dunes, increases hydraulic roughness, promotes sediment deposition, and inhibits dune propagation due to wind suspension [6]. Due to salinity and flooding gradients, a vegetation zonation is produced, favouring high biodiversity [6, 9]. Tide influences the wetland through rising of sea level, and promotes a wave of groundwater level oscillation that diffuses through the system, slowly if through the subsurface, or fast if surface water mediated $[8,10]$.

Studies available on coastal wetlands have shown interesting connections between the hydrology and ecology; in particular, relevant studies associated to our investigation include those at other similar Mediterranean regions such as: eastern Spain [7, 11], Portugal [12], Italy [8], Greece [5], Australia [13] and México [14].

The most important wetland complex in central Chile is El Yali. This area presents a high seasonal dynamism (winter-summer), plus interannual cycles due to El Niño Southern Oscillation (ENSO), and is the only wetland area in the neotropics protected by the Ramsar Convention [15]. It is key habitat for migratory birds - more than 115 species, which represent more than $25 \%$ of native Chilean bird species diversity [16]. Plant biodiversity is not very high, but it is a unique ecosystem being a northern distribution limit for typical palustrian plant species (e.g. Spartina densiflora) and southern distribution limit for typical halophyte species from northern Chile (e.g. Salicornia fruticosa).

The coastal lagoon (Fig. 1) attracts particular attention: it is one of the few water bodies that is encapsulated totally inside the reserve; it attracts a mixed diversity of sea and inland species; and is being threatened by human activities directly (cattle trespassing, stream flow regime alterations, tourist settlements) and indirectly (high income crop production, urbanization, wastewater discharges to streams and soils). Though unique, several other wetlands in the coastal central region of Chile share a similar context of coastal eroded watersheds undergoing rapid land use changes that may affect coastal ecosystem productivity [17], dynamics (seasonal streamflow opens outlet bars in winter months but disconnects the estuary for most of the year), and ecological importance (habitat for migratory bird, fish and other species). The area has been the subject of some recent ecological studies concerning mainly riparian vegetation distribution [18].

Our general goal is to understand lagoon hydrology and connections to ecology in this a unique site, as well as for use as a template for other similar functioning systems in central Chile. This investigation thus represents a first step in this direction, seeking to gain further understanding of the relationship between sea and lagoon water level, as mediated by the lagoonocean connectedness through the Yali stream mouth. We use a combination of field observations, time series analysis, and numerical modelling of the lagoon-ocean level interaction to demonstrate the main influence of sea level on lagoon's water level and possible connections to riparian groundwater levels. 


\section{Methods}

\subsection{Study site}

The climate in the area is Mediterranean with oceanic influence and marked seasonality. Autumn-winter (May-August) rainfall represents $90 \%$ of the annual rainfall, followed by a long period of 7 dry months [19]. This dictates the Yali stream flow regime, with an estimated average (there is no gauging station) annual flow of $1.2 \mathrm{~m}^{3} / \mathrm{s}$, mostly during half of the year with negligible flows during the dry season. Based on local data (station $10 \mathrm{~km}$ from lagoon), mean annual rainfall is $481 \mathrm{~mm}$, while potential evaporation in the area has been estimated as 1500 $\mathrm{mm}[20,21]$.

The coastal lagoon has an elongated shape parallel to the beach, being formed by the interplay of Yali streamflow and ocean influence mediated by a mouth that closes in the dry season (Fig. 1). During dry months, stream flow is not enough to prevent a bar closure of the outlet to the ocean, a period we will refer to as 'disconnected'. Following the classification of Cooper [22], the lagoon would be a 'non-perched closed estuary', with no high berm (low sand bar), sporadic surface channel connection to the ocean, dissipative (low gradient) profile beaches and wide surf zones, with salt marsh vegetation. The lagoon is very shallow (less than $0.5 \mathrm{~m}$ average depth), which together with windy conditions provide a very well mixed water column [23]. The surface channel typically is also very shallow, with only a few $\mathrm{cm}$ depth and several meters wide. Disconnected periods provide very stable water area and volume, and thus a more stable habitat [22]. Due to high evaporation potential, lagoon water is very saline, particularly as the dry period advances (disconnected phase). Nevertheless, we note that the Yali lagoon is different from the South African systems described by Cooper [22], since the outlet is seasonal [23].

We have postulated $[23,24]$ that the lagoon hydrologic balance is a function of the following elements with different importance depending on season (conceptual model in Fig. 2):

$$
\frac{d S}{d t}=R^{*}-E+Q_{Y}^{*}\left(+Q_{D}^{*}\right)+Q_{s} \pm Q_{G S} \pm Q_{S S}^{*}\left(+Q_{O S}\right)
$$

where the terms are (an asterisk * indicates that the flux occurs only during winter, i.e. the rainy season) the following: $S$, lagoon water storage; $R^{*}$, rainfall; $E$, lagoon evaporation; surface inflow, $Q_{Y}{ }^{*}$ from Yali stream, and $Q_{D}{ }^{*}$, drainage ditch flows, which mainly occur during storms due to soil saturation [24]; $Q_{S}$, groundwater discharge from the upland aquifer; $Q_{G S}$, subsurface flows from/to the ocean due to sea level vs. lagoon water level difference; and surface water connection with the ocean $Q_{S S}{ }^{*}$, due to tide influence through open inlet part of the year (together with $Q_{O S}$, occasional storm surge over washing, in parentheses). Note that we have do not include stormwater overland flow since the soil is highly permeable sand, and that we are not reporting estimates for many of the water budget fluxes mentioned above, due to lack of data and monitoring availability, as well as that is not the objective of this paper but of future work.

\subsection{Monitoring methods}

Due to the lagoon configuration, one can recognize two distinct groundwater zones: one upslope from the lagoon, where groundwater flows from the watershed aquifer and discharges into the lagoon [20,21], and the other being the sand bar between lagoon and ocean, including the beach [23]. For groundwater monitoring, 3 piezometer transects were installed in 2004-2005, perpendicular to the beach-lagoon longitudinal axis (Fig. 2), so as to investigate aquifer 
connection (2-3 piezometers in southeast/upslope side) but principally, at least at this stage, sealagoon connectivity ( 3 piezometers in northwest/sea side). Piezometer lengths were 1 to $2 \mathrm{~m}$ deep. Water levels were initially measured in seasonal scouting campaigns, and starting January 2006 using TruTrack ${ }^{\mathrm{TM}}$ transducer sensors $( \pm 1 \mathrm{~cm}$ precision) in 10-minute intervals [23]. Sea level data in hourly intervals were provided by the Navy Oceanographic Station in San Antonio, $20 \mathrm{~km}$ from the site. Typical tide amplitude range is $1.2 \mathrm{~m}$ (i.e. Yali stream mouth is a microtidal estuary). Daily rainfall data are recorded at a station $10 \mathrm{~km}$ from the lagoon, assumed to be the same due to Chilean frontal type rainstorms and same altitude. Wind data (hourly intensity and direction from 9 am to $6 \mathrm{pm}$ ) are registered at another station $15 \mathrm{~km}$ from Yali wetland, again at similar altitude and exposition. A summary of the data used is presented in Table 1.

Saturated hydraulic conductivity was estimated using constant head permeameter tests on samples collected when piezometers were installed, and complemented with measurements taken later using a tensio-infiltrometer [23, 24]. Lagoon bottom sediment permeability was estimated using seepage meters installed in 5 locations and using average measured heads in the $15-20 \mathrm{~m}$ vicinity as an approximation.

Since there is concern of anthropogenic eutrophication from the viewpoint of natural resource managers (Corporación Nacional Forestal, CONAF), who provided field access and support, and there might be interest in comparing to other similar systems worldwide, we provide some summarized reference data (which will be published in full in a future paper based on synthesis of ongoing work [23, 24]). Due to the strong dependence of lagoon level to tides while connected to the sea, water quality measurements have been done monthly on full moon days, when the maximum tidal amplitude differences are registered, and therefore higher fluxes are assumed to occur. Measurements included dissolved oxygen, $\mathrm{pH}$, and conductivity with on-site sensors; and nutrients from samples stored at $4^{\circ} \mathrm{C}$, filtered, and analyzed with spectro-photometer methods. Table 2 summarizes methods.

\subsection{Data analysis}

To analyze the relation between sea level and lagoon depth time series, we used several methods, including: (i) typical average pattern repetition and residual analysis [25], to identify average characteristics of rising and recessing cyclic periods; (ii) frequency spectrums, to identify most important frequencies of processes affecting water level, in connected and disconnected phases; (iii) Fourier analysis, to relate sea to lagoon water level, through a typical Impulse Response Function approach [26]; and (iv) a simplified numerical model based on Darcy's equation applied to an unconfined aquifer, assuming only lateral flow (Dupuit approximation), thus reducing to a diffusion-type equation:

$$
\begin{aligned}
& \frac{\partial h}{\partial t}-D \cdot \frac{\partial^{2} h}{\partial x^{2}}=\frac{w}{p} \\
& D=k a / p
\end{aligned}
$$

where $h$ is hydraulic head [L], measured; $w$ is the rainfall rate [L/T], measured; $D$ diffusion coefficient, assumed constant, given by equation 3 , with $k$ saturated hydraulic conductivity $[\mathrm{L} / \mathrm{T}]$, estimated, $a$ is the aquifer's thickness [L] (approximately $100 \mathrm{~m} \mathrm{[27]),} \mathrm{and} p$ is soil porosity $\left[\mathrm{L}^{3} / \mathrm{L}^{3}\right]$, measured. This partial differential equation was solved for $h$ with a fully implicit 
method, using hourly lagoon water level and sea level data as boundary conditions, and the initial condition being an interpolation between both.

\section{Results and discussion}

\subsection{Soil hydraulics}

Soils in the vicinity of the lagoon are coarse and relatively homogeneous $\left(D_{50}=0.18 \mathrm{~mm}\right.$, porosity $=0.43$ ), primarily sand with some gravel. $\mathrm{K}_{\mathrm{s}}$, soil saturated hydraulic conductivity, was measured both in the field (using a tensioinfiltrometer) and in the lab (permeameter measurements from soil samples taken from piezometer installation). It ranged from 0.80 to $13 \mathrm{~m}$ $\mathrm{d}^{-1}$ on the upslope (SE) side; the sea (NW) side $\mathrm{K}_{\mathrm{s}}$ ranged from 0.53 to $15 \mathrm{~m} \mathrm{~d}^{-1}$.

From low flows measured in all seepage meters, the estimated lagoon bottom sediment mean conductivity was estimated as $0.015 \mathrm{~m} \mathrm{~d}^{-1}$, at least an order of magnitude lower than riparian soil $\mathrm{K}_{\mathrm{s}}$ reported above. This implies that probably most of the flow to and from the ocean $\left(\mathrm{Q}_{\mathrm{GS}}\right)$ would occur through riparian zones, if there was a head difference between sea and lagoon water levels.

\subsection{Lagoon water level fluctuations}

During the disconnected phase of the summer-autumn of 2006 (November to June), lagoon levels varied almost negligibly, as seen in Fig. 3 (NB: sea level was converted into relative height above our reference point, where average sea level was $98.5 \mathrm{~m}$ ). The only exceptions were on days of high winds - see Fig. 3a. In early winter, due to rainfall events, Yali streamflow eroded the bar that had closed the stream mouth during the previous dry season (Fig. 3b). Then the lagoon and the ocean were connected through the outlet, inducing a daily oscillation in the lagoon water level (Fig. 3b, c). Disconnection during the study period occurred during mid September. About a week before closure, the periodic fluctuation of water levels was replaced by stepwise increases, until water levels stabilized circa September $18^{\text {th }}$ with the bar finally closed (Fig. 3d).

Conversely, during the connected phase the lagoon level amplitude difference averaged 20 $\mathrm{cm}$, varying between 8 and $80 \mathrm{~cm}( \pm 2 \mathrm{~cm})$, depending on tide. An analysis of the average pattern (Fig. 4) for 10-minute data from June 10 to September 15 showed that it typically took four hours to reach peak lagoon level after a sea level threshold was surpassed by the rising tide (related to the outlet base level, as discussed further below). This peak was followed by sea level dropping below lagoon level, just after high tide, in the sea recession limb (residual errors in the average pattern with mean 0.0137 and standard deviation 0.0705). For the recession that followed, it took approximately 13 hrs to return to initial levels, when a new inundation cycle was initiated.

Spectral analysis of lagoon (Fig. 5) vs. sea levels showed that the most important frequencies in decreasing order are $12.5 \mathrm{hrs}$ (high tides), $24.2 \mathrm{hrs}$ (tidal daily cycle) and 16.4 days (moon cycles). Sea data revealed a peak at $12.5 \mathrm{hrs}$ and another lesser one at $23.7 \mathrm{hrs}$ (not shown).

When the outlet bar formed and the lagoon disconnected from the ocean, there was no apparent relationship between sea level and lagoon level - for example, spectral analysis only reveals a slight peak at period 0.997 days. The lagoon level varied little during the day (only a few millimetres) for any tide amplitude, as exemplified for February 2006 (Fig. 3d).

However, an exception occurred during February $13^{\text {th }}$, attributed to strong winds that probably produced a slope in the lagoon level. This wind effects were most pronounced during the 
disconnected phase. An analysis of wind data showed winds were stronger when wind direction was from the SE, closer to the lagoon longitudinal axis, and directed towards the transect area (correlations not shown, average 0.715 ), as well as the reverse direction, when a decrease in level occurred, attributed to an opposite sloping effect. Correlations were negative when wind direction was perpendicular to lagoon, indicating that the slope went upstream instead. Further studies are needed, including monitoring with a transducer in the extreme SE of the lagoon.

Based on the data gathered, rainfall had little effect over lagoon water level, except for those events that opened the outlet bar in the disconnected situation. In sum, the overriding influence on lagoon level was sea level fluctuations. Nevertheless, with rainfall the groundwater level between lagoon and ocean increased very quickly (Fig. 3c), probably due to the highly conductive porous media.

\subsection{Water level numerical analysis}

A Fourier analysis performed in Matlab ${ }^{\mathrm{TM}}$ (Fig. 6) applied to hourly sea and lagoon time series revealed that a simple Impulse-Response Function of exponential form $\exp (-t / 2.5)$ fit the sea-lagoon relation very well, with an appropriate threshold related to the outlet base level ( 98.67 $\mathrm{m}$; i.e. approx. $15-20 \mathrm{~cm}$ above mean sea level during connected phase). This is supported by our field physical interpretation of the level data series (Fig. 3): when the lagoon level reached a peak, it corresponded to the maximum sea level, and initial recession was controlled by fast outflow through the outlet with descending sea level. But once the lagoon level reached outlet level (and if sea level was lower than outlet base level, at $98.67 \mathrm{~m}$ in Fig. 3), the recession took place at a slower rate, probably linked to slower porous media flow through the sand berm to the ocean (Fig. 3). Another possibility is that once the level drops below a certain level, stream water flows in, dampening the recession drop; this would be improbable during the connected phase due to negligible dry season streamflow.

Modelling simulations for water levels in the central transect, using the Dupuit approximation given in equation 1, were done for the range of $k$ values measured.

To include partially some adjustment due to density dependence, water levels for the boundary conditions (sea and lagoon level data) were corrected as a linear function of salinity content, using the Ghyben-Herzberg equation that provides an empirical first approximation in natural (more or less static) coastal aquifers [23]. This approach resulted in multipliers 1.0291 and 1.0270 for sea and lagoon hydraulic heads, respectively. Initial conditions were an interpolation between both boundary conditions at July $14^{\text {th }} 2006$, which explains why it took 2-3 days for the initial condition error to propagate and finally diffuse, as seen in Fig. 7.

Fig. 7 shows results for the best-fit parameter values in the high end range for $k$ (approximately $10^{-4} \mathrm{~m} \mathrm{~s}^{-1}$, in accordance with the values reported - see section 3.1). The results adjusted well for the general trends in amplitude oscillations and periods. The smaller scale mismatch is attributed to differing salinities between boundary conditions and possibly other density-dependent effects. Additionally, the vertical beach boundary condition might be affecting this kind of simulation. Given the aquifer estimated depth of $100 \mathrm{~m}$ and soil porosity of 0.43 , the diffusivity coefficient $D$, computed from equation 3 , was $2.3 \times 10^{-2} \mathrm{~m}^{2} / \mathrm{s}$.

\subsection{Water quality}

Concerning water quality, groundwater $\mathrm{pH}$ averaged 7.1 (range: 6.5 to 7.6 ), while lagoon and sea values were very stable, 8.6 and 8.1, respectively. Dissolved oxygen did not show a defined spatial pattern (groundwater 2-4 $\mathrm{mg} \mathrm{L}^{-1}$, sea and lagoon 7-9 $\mathrm{mg} \mathrm{L}^{-1}$, with a maximum in the latter 
of $\left.12 \mathrm{mg} \mathrm{L}^{-1}\right)$.

Groundwater discharge from upslope into the lagoon was fresh (average conductivity lower than $0.7 \mathrm{mS} \mathrm{cm} \mathrm{cm}^{-1}$, increasing to $4-5$ close to the lagoon). Annual mean conductivity for the lagoon was $51.9 \mathrm{mS} \mathrm{cm}^{-1}$ for 2006 , with values ranging from 20 to $100 \mathrm{mS} \mathrm{cm}^{-1}$ (higher values in summer as would be expected). Increased salinity/conductivity in the lagoon was linked to seawater intrusion and evaporation in the shallow system, known to happen in this type of system [28].

Phosphate in groundwater exhibited (data not shown) a gradient of progressive decrease towards the sea with some very high values upslope from the lagoon and in nearby drainage ditches discharging into the lagoon, over $1.5 \mathrm{mg} / \mathrm{L}$ P-PO ${ }_{4}$. Possible sources include agricultural fertilizers, organic deposits of past poultry operations, as well as cattle illegally introduced into the wetland area for grazing. Lagoon phosphate concentrations, however, showed a narrow range: $0.1-0.5 \mathrm{mg} / \mathrm{L} \mathrm{P}-\mathrm{PO}_{4}$. Nitrate results are under revision due to possible interferences in the method, and are not reported here, initial evidence suggests this is the limiting nutrient in the lagoon and riparian area [18].

\section{Conclusions and further work}

Based on our initial observations and data collection, Yali lagoon water level dynamics appear to be driven by sea level and streamflow variability. Our results suggest that these factors that can be organized hierarchically. The upper hierarchical level is seasonal: lagoon level responds to the lagoon surface water being connected or disconnected to the ocean through the outlet.

During disconnection (summer-autumn), the lagoon level is generally independent of sea level, even though there is a $150 \mathrm{~m}$ porous sand bar between the two. Apparently, dampening is enough to minimize the effect of groundwater pressure wave. The bar is occasionally overtopped by storms, which could affect lagoon water level temporarily. Nevertheless, such events were not observed during our data collection in 2006.

Conversely, during the connection phase two lower level temporal scale hierarchies are relevant: monthly (moon cycles every 16.4 days on average) and daily (tidal cycles every 12.5 and $24.2 \mathrm{hrs}$ ), as the pattern, spectral, and Fourier analyses have shown.

Wind effects can be important particularly during the disconnected phase, while in the connected phase, these are overridden by the ocean level factor. Rainfall events seem to be not an important driver for lagoon level, except for those rains that change the phase from disconnected to connected, i.e. that interact with the higher temporal scale hierarchy.

Numerical analysis results show that a simple exponential Impulse-Response Function relates the sea forcing to lagoon level during the connected phase. Additionally, a simple Dupuit numerical model gives a reasonable approximation of piezometer water level trends between sea and lagoon, even though there are salinity and beach slope effects that deserve further attention. Also, as we have observed since 2003, sea storms, El Niño events, and general interannual variability will affect water exchanges, so we plan to continue monitoring and incorporating new data into our analyses.

Water quality monitoring has shown the potential presence of a double salt wedge, as well as a phosphate high concentration zone just upslope of the lagoon, that likely relates to illegal cattle entrance and past poultry operation waste. This will be investigated further since it is a cause of concern for the management of this unique coastal wetland.

In the near future, we hope to use the tools presented here, complemented with additional ones 
(e.g. complete water balance, density-dependent modelling, extensive data gathering) and findings by an ecology team working in the area, to continue our study of this system, examining topics such as water level versus plant distribution relationships for different scenarios in sea and lagoon level dynamics.

\section{Acknowledgements}

Authors would like to thank our collaborator, ecologist J. M. Fariña, and CONAF managers. Data were provided by the Navy, Dirección Meteorológica de Chile, and Dirección General de Aguas. M. Sepúlveda and Agrosuper S.A. (through C. Vives) provided private reports. Useful suggestions for data analysis were provided by B. Fernández, W. Palma, P. Irarrázaval, and R. Cienfuegos. Special thanks to P. Pastén for providing equipment. We would like to thank also A. Packman, E. Barthelemy and S. Tyler for fruitful field discussions, as well as J. Aravena, F. Varas and E. Mignot and all the people that helped us in the coastal lagoon site. Special thanks to the two anonymous reviewers, as well as to Dr. Brack Hale, for their useful suggestions that substantially improved the more effective communication of this work.

\section{References}

[1] Suzuki, M. S., Ovalle, A. R. C., Pereira, E. A. Effects of sand bar openings on some limnological variables in a hypertrophic tropical coastal lagoon of Brazil. Hydrobiologia, 368 (1998) 111-122.

[2] Mitsch, W. J., Gosselink, J. G. Wetlands. John Wiley \& Sons. Inc., New York, 2000.

[3] Dall'o', M., Kluge, W., Bartels, F. FEUWAnet: a multi-box water level and lateral exchange model for riparian wetland. Journal of Hydrology, 250 (1-4), (2001) 40-62.

[4] Krasnostein, A. L., Oldham, C. E. Predicting wetland water storage. Water Resources Research, 40 (10), (2004) W10203.

[5] Sylaios, G., Theocharis, V. Hydrology and nutrient enrichment at two coastal lagoon systems in Northern Greece. Water Resources Management, 16 (3), (2002) 171-196.

[6] Ursino, N., Silvestri, S., Marani, M. Subsurface flow and vegetation patterns in tidal environments. Water Resources Research, 40 (5), (2004) W05115.

[7] Perez-Ruzafa, A., Fernandez, A. I., Marcos, C., Gilabert, J., Quispe, J. I., Garcia-Charton, J. A. Spatial and temporal variations of hydrological conditions, nutrients and chlorophyll a in a Mediterranean coastal lagoon (May Menor, Spain). Hydrobiologia, 550 (2005) 11-27.

[8] Marani, M., Silvestri, S., Belluco, E., Ursino, N., Comerlati, A., Tosatto, O., Putti, M. Spatial organization and ecohydrological interactions in oxygen-limited vegetation ecosystems. Water Resources Research, 42 (6), (2006) W06D06.

[9] Greenblatt, M. S., Sobey, R. J. Subsurface flow and transport in tidal wetlands: Marsh plain equations. Journal of Engineering Mechanics-ASCE, 125, (1999) 971-974.

[10] Chen, B. F., Hsu, S. M. Numerical study of tidal effects on seawater intrusion in confined and unconfined aquifers by time-independent finite-difference method. Journal of Waterway Port Coastal and Ocean Engineering-Asce, 130, (2004) 191-206

[11] Lopez-Flores, R., Quintana, X. D., Salvado, V., Hidalgo, M., Sala, L., Moreno-Amich, R. Comparison of nutrient and contaminant fluxes in two areas with different hydrological regimes (Emporda Wetlands, NE Spain). Water Research, 37, (2003) 3034-3046

[12] Newton, A., Mudge, S. M. Lagoon-sea exchanges, nutrient dynamics and water quality management of the Ria Formosa (Portugal). Estuarine Coastal and Shelf Science, 62, (2005) 405-414 
[13] Marimuthu, S., Reynolds, D. A., La Salle, C. L. A field study of hydraulic, geochemical and stable isotope relationships in a coastal wetlands system. Journal of Hydrology, 315, (2005) 93-11.

[14] Contreras-Espinoza, Zabalegui-Medina. Hidrología, nutrientes y productividad primaria en la laguna La Joya-Buenavista, Chiapas, México. Anales del Instituto de Ciencias del Mar y Limnología, Mèxico. 1991.

[15] Möder, L., Gallardo, H., Vilina, Y. A. Ficha informativa de los humedales de Ramsar. Humedal El Yali. 2002.

[16] Leiva, I., Meza, J., Möder, L. Boletin Técnico No 59: "Fundamentos para la creación de la Reserva Nacional El Yali". CONAF V Región. Government Report. 1995.

[17] Andrade B., Grau S. La laguna de Cahuil, un ejemplo de estuario estacional en Chile central. Revista Geografia Norte Grande 33: (2005) 59-72.

[18] Farina J.M. Third year report to CONAF on advanced research of riparian vegetation dynamics. Unpublished document. 2006.

[19] Fernández, J. V. Proposición de un plan de manejo integral de la cuenca hidrográfica del Estero Yali, V y Región Metropolitana. Tesis Ingeniero Forestal, Ciencias Silvoagropecuarias, Universidad Mayor, Chile. 2004.

[20] APR_Ingeniería_SA. Evaluación de recursos hídricos subterráneos cuenca del Estero Yali: informe final. Private Report. 2000.

[21] Geometra_Ltda. Evaluación hidrológica e hidrogeológica en la cuenca del estero El Yali. Private Report. 1995.

[22] Cooper J.A.G. Geomorphological variability among microtidal estuaries from the wavedominated South African coast. Geomorphology 40: (2001) 99-122.

[23] Galdames, P. Yali lagoon hydrology, with emphasis on subsurface processes. M.Sc. Thesis, P. Universidad Católica, Chile (in Spanish). 2006.

[24] Sun, C-L. Yali lagoon hydrology, with emphasis on surface water processes. M.Eng. dissertation, P. Universidad Católica, Chile (preliminary draft in Spanish). 2008.

[25] Salas, J. D., Delleur, J. W., Yevjevich, V., Lane, W. L. Applied Modeling of Hydrologic Time Series. Water Resources Publications, Littleton (CO), USA. 1980.

[26] Weber WJ, Digiano FA. Process dynamics in environmental systems. Wiley, New York. 943 pp. 1996.

[27] MOP Informe técnico $\mathrm{N}^{\circ}$ 421: Area de restricción sector hidrogeológico de aprovechamiento común de Yali bajo El Prado. Ministerio de Obras Públicas, Gobierno de Chile. Government Report. 2005.

[28] Diamantopoulou E., Dassenakis M., Kastritis A., Tomara V., Paraskevopoulou V., Poulos S. Seasonal fluctuations of nutrients in a hypersaline Mediterranean lagoon. Desalination 224: (2008) 271-279. 


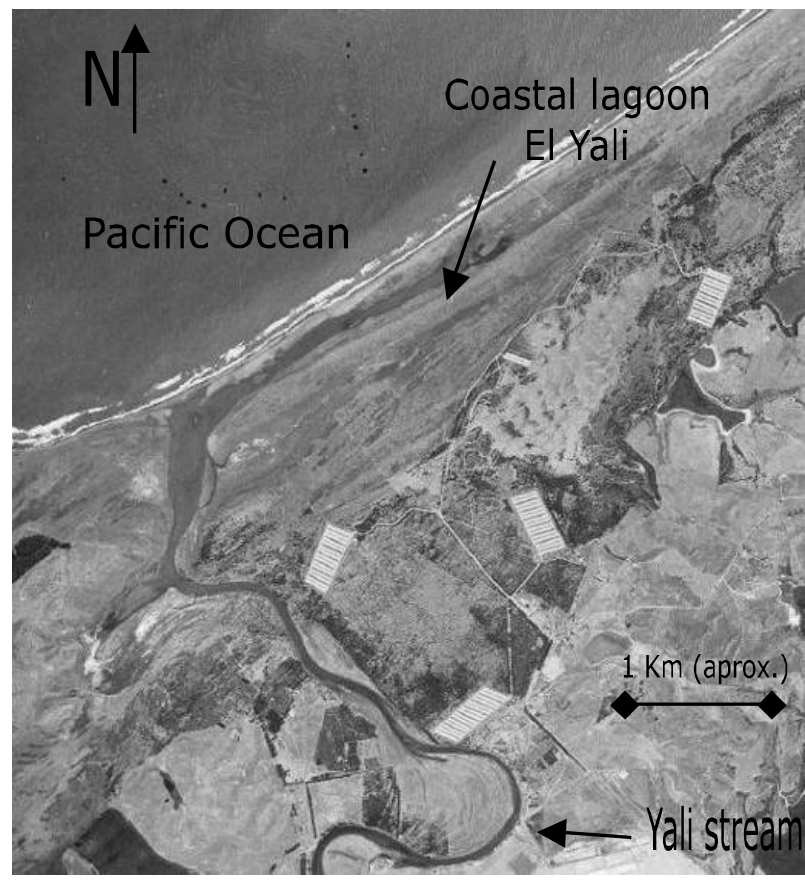

Fig. 1. Yali coastal lagoon (CONAF 1998) 


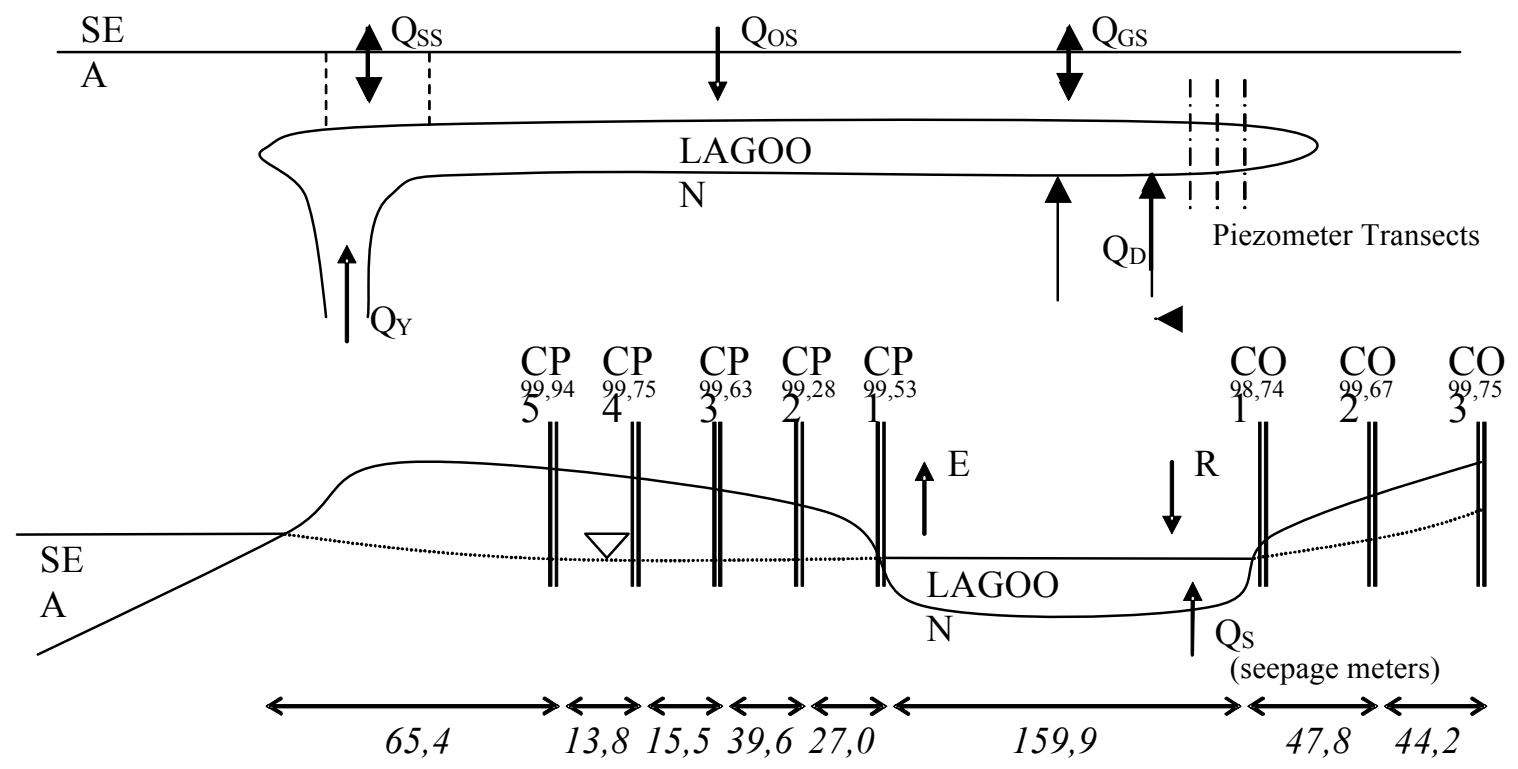

Fig. 2. Conceptual diagram of hydrological fluxes: plain view (top, piezometer transects shown) and cross section view of central piezometer transect (bottom, seepage meter location shown, and with central transect coding: CP for between sea and lagoon and CO for upslope lower numbers given to piezometers closer to the lagoon, with relative height of transducer under the respective piezometer code, and horizontal spacing, in cursive, at the figure bottom) - all numbers in meters. 
a)

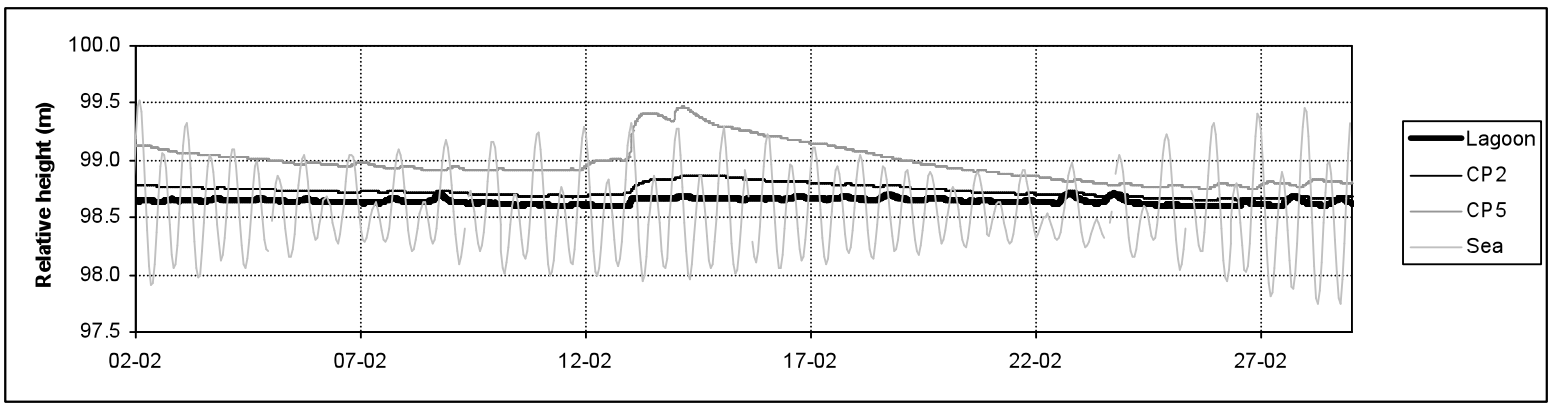

b)

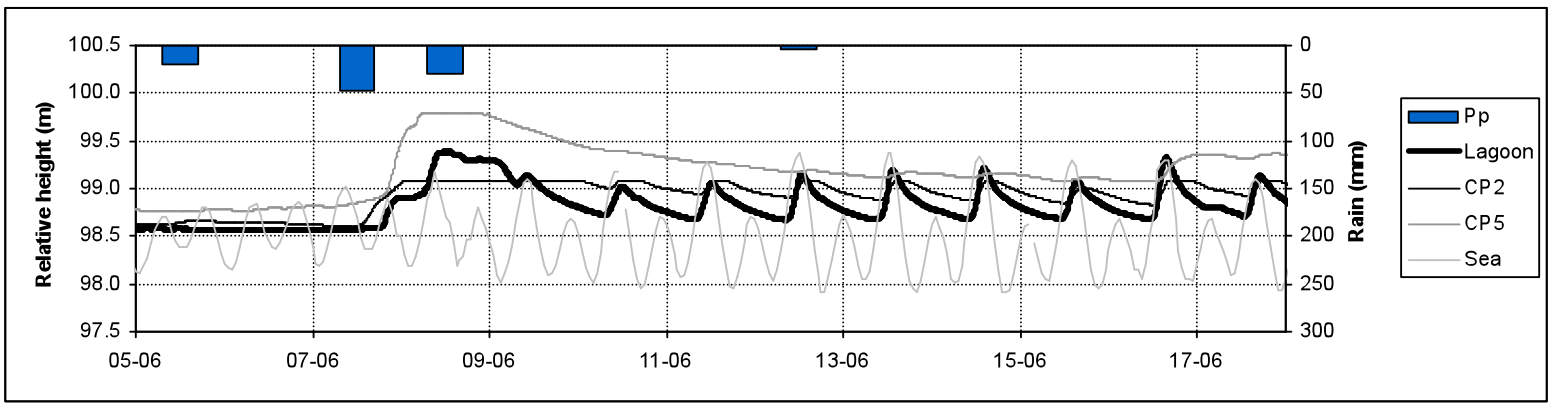

c)

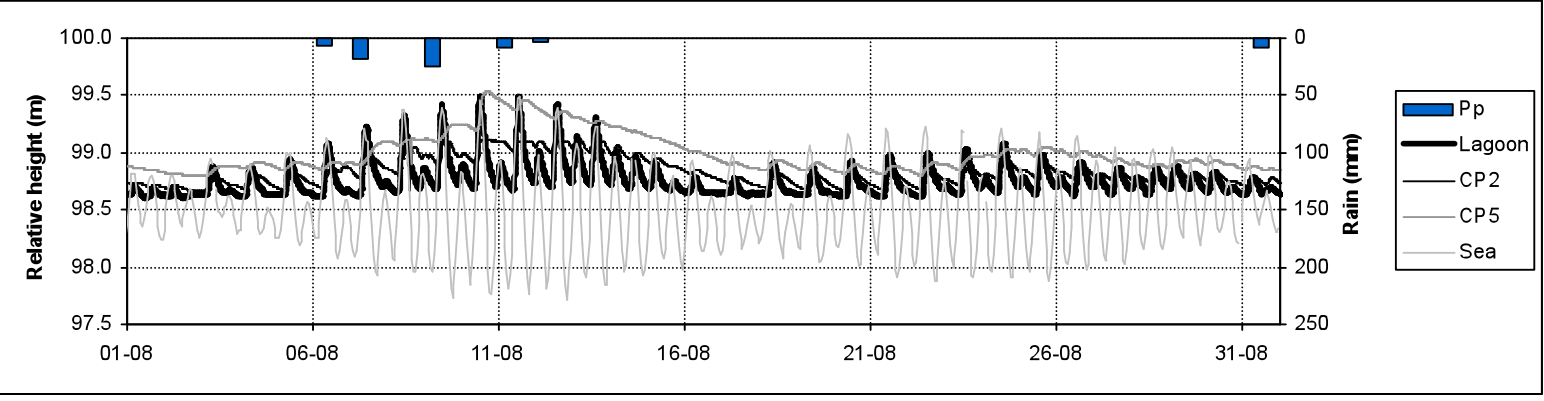

d)

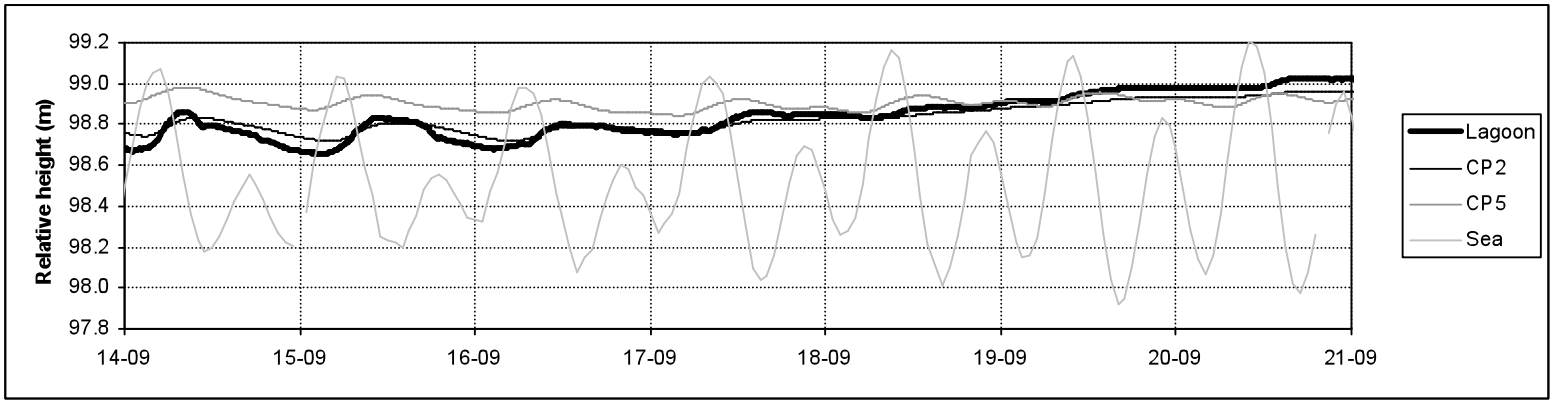

Fig. 3. Water level behavior during 2006 for lagoon (thick line), sea level (light grey - mean average sea level was $98.5 \mathrm{~m}$ relative to the reference used), and piezometer water level in transect from sea to lagoon (CP2 and CP5 -see Fig. 2- in mid gray tones) for example periods of: a) disconnection, no rainfall but a strong summer $\mathrm{S}$ wind event; $\mathrm{b}$ ) first winter season rainstorm June 6-8 (Pp bars) that opens the inlet bar by June 8th, changing from lagoon status from disconnected to connected (ZOOM); c) connection, with a frontal rain system August 712; and d) transition from connection to disconnection during mid-September (ZOOM). 


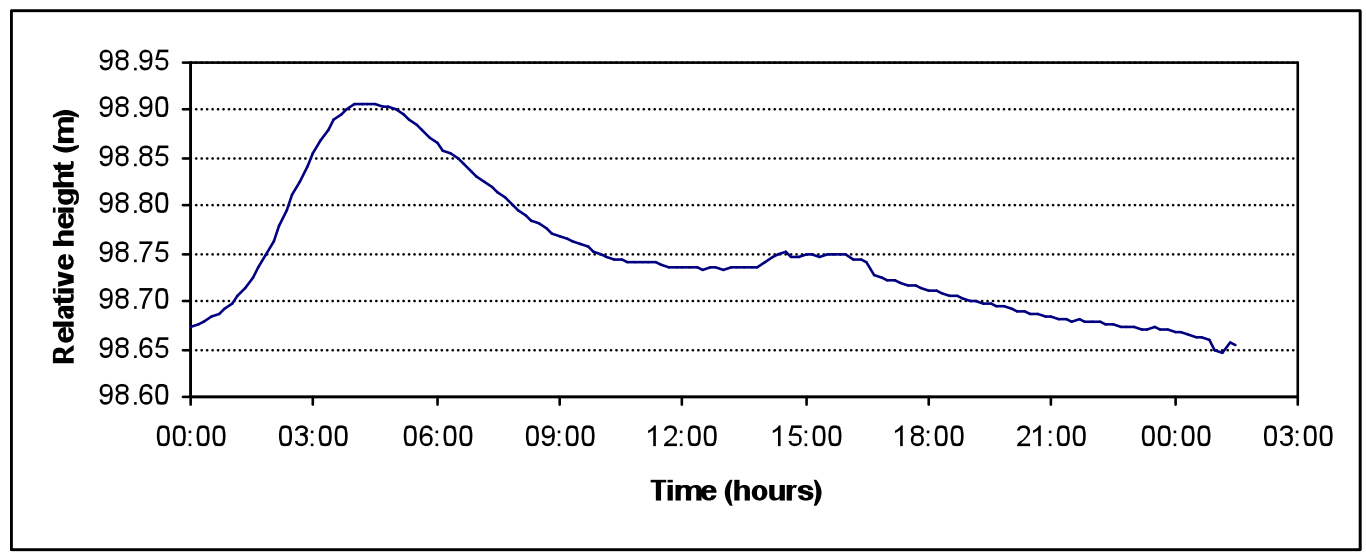

Fig. 4. Typical behavior pattern in lagoon water level periodical oscillations based on 10minute data from June 10 to September 15, 2006. 


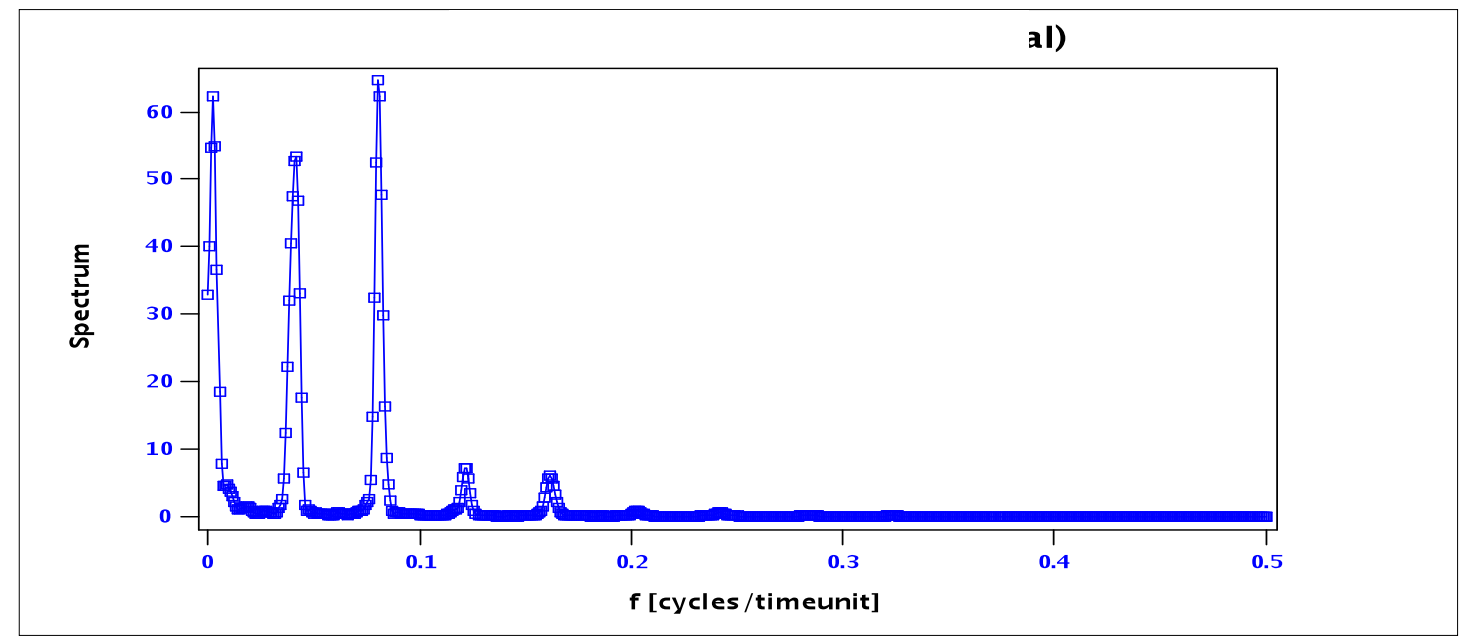

Fig. 5. Spectral analysis for lagoon water level from July 13 to August 31, 2006, based on hourly data and time unit of $24 \mathrm{hrs}$. 


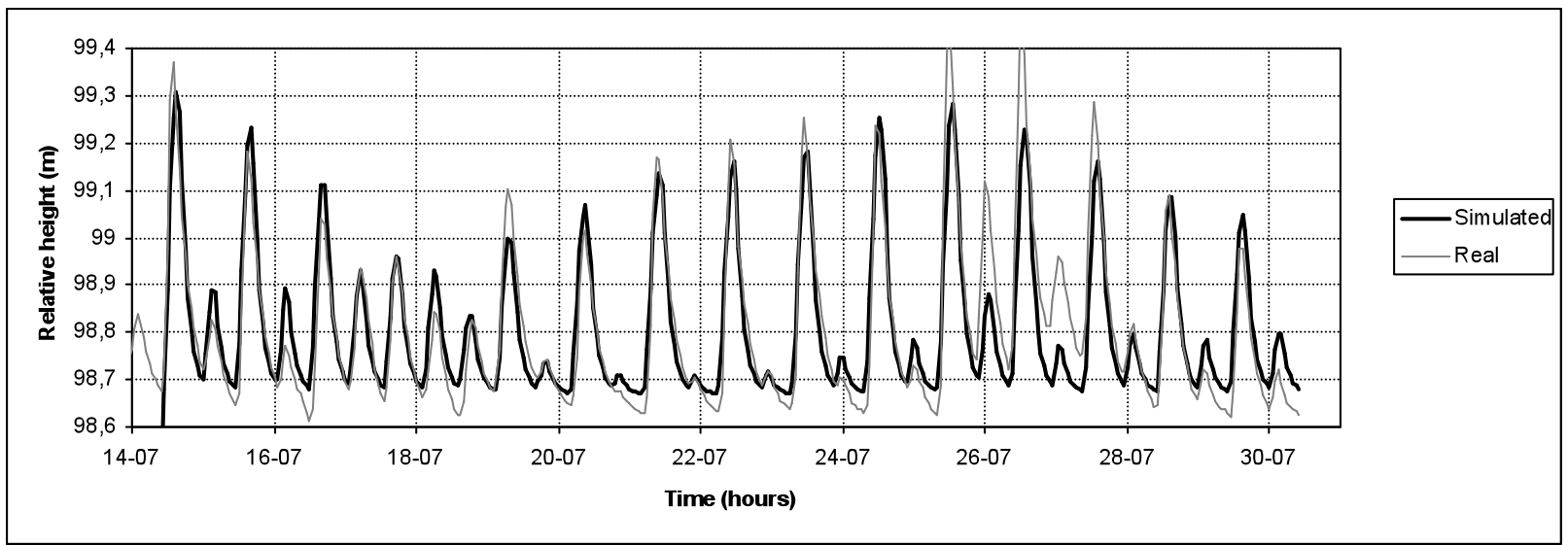

Fig. 6. Fourier analysis for lagoon water level from July 13 to August 31, 2006, based on hourly data. 
a)

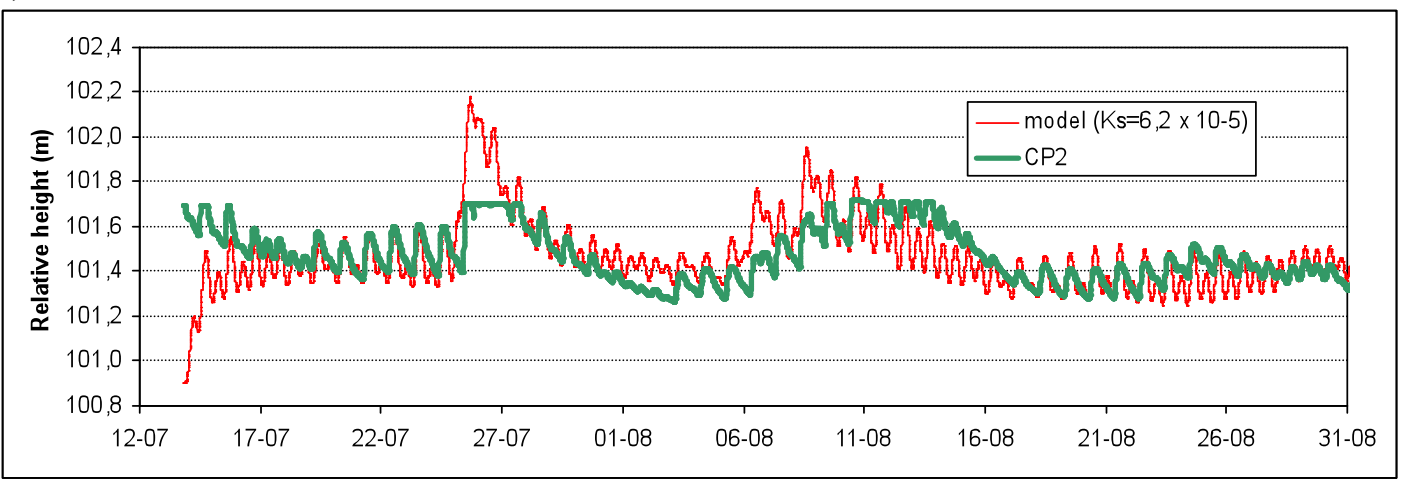

b)

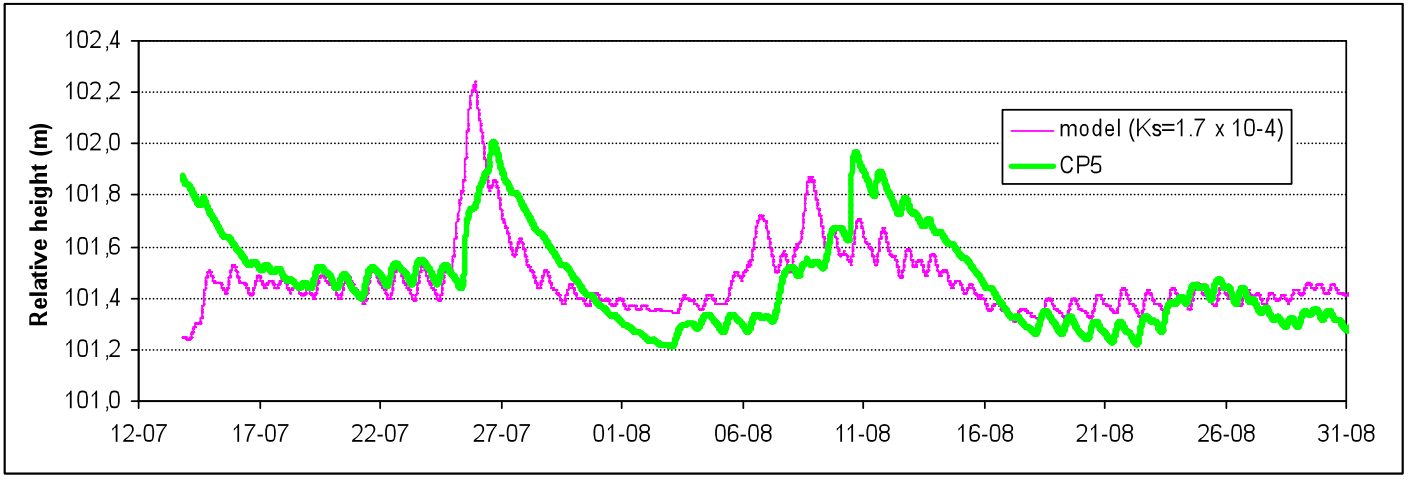

Fig. 7. Modelling results (thin line; saturated hydraulic conductivity Ks reported) vs. piezometer data (thick line) comparison of groundwater levels for the sand bar between lagoon and sea, for the central transect piezometers (see Fig. 2): a) CP2 (closer to lagoon in riparian vegetation area; note that since 101.7 is the maximum recordable relative height by this piezometer, there is an artificial plateau in the graph); b) CP5 (close to topographic peak of sand dune, nearer the seaside). 
Table 1

Summary of data used

\begin{tabular}{lllll}
\hline Type of data & Unit & Resolution & Precision & Range \\
\hline Water level & $\mathrm{m}$ & 10 minute mean & $\pm 1 \mathrm{~cm}$ & Jan-Nov 2006 \\
Sea level & $\mathrm{m}$ & Hourly mean & $\pm 1 \mathrm{~cm}$ & Jan-Nov 2006 \\
Rainfall & $\mathrm{mm}$ & Daily & $\pm 0.25 \mathrm{~mm}$ & Jan-Sep 2006 \\
Wind & $\mathrm{m} / \mathrm{s}$ & Hourly (9-18 hrs) & $\pm 0.1 \mathrm{~m} / \mathrm{s}$ & Jan-Sep 2006 \\
\hline
\end{tabular}




\section{Table 2}

Water quality equipment and methods used

\begin{tabular}{|c|c|c|c|}
\hline Instrument (brand) & Parameter & Precision & Range \\
\hline WT-HR (TruTrack) & Temperature & $\pm 0.1^{\circ} \mathrm{C}$ & $-30{ }^{\circ} \mathrm{C}$ to $+70^{\circ} \mathrm{C}$ \\
\hline Sension5 $(\mathrm{HACH})^{\dagger}$ & Conductivity ${ }^{*}$ & $\pm 0.5 \%{ }^{*}$ & $0.00 \mu \mathrm{S} / \mathrm{cm}$ to $199.9 \mathrm{mS} / \mathrm{cm}$ \\
\hline & Salinity & $\pm 0.1 \%$ & 0 to $42 \%$ \\
\hline & $\mathrm{TDS}^{\ddagger}$ & $\pm 0.5 \%{ }^{*}$ & $0.00 \mathrm{mg} / \mathrm{L}$ to $50 \mathrm{~g} / \mathrm{L}$ \\
\hline $\begin{array}{l}\text { Triode } \mathrm{pH} \text { Electrode } \\
\text { (Thermo Orion) }\end{array}$ & $\mathrm{pH}$ & \pm 0.1 & 0 to 14 \\
\hline DO 100 (Oakton) $^{a}$ & OD & $\pm 1.5 \%{ }^{*}$ & $\begin{array}{l}0 \text { to } 20.00 \mathrm{mg} / \mathrm{L} \\
0 \text { to } 200.0 \%\end{array}$ \\
\hline Spectrophotometer & $\mathrm{N}-\mathrm{NO}_{3}^{-}$ & $\pm 0.10 \mathrm{mg} \mathrm{N}-\mathrm{NO}_{3}{ }^{-} / \mathrm{L}$ & 0.0 to $4.5 \mathrm{mg} \mathrm{N}-\mathrm{NO}_{3}{ }^{-} / \mathrm{L}$ \\
\hline DR/2010 (HACH) & $\mathrm{P}_{-} \mathrm{PO}_{4}$ & $\begin{array}{l} \pm 0.01 \mathrm{mg} \mathrm{PO}{ }^{3-} / \mathrm{L} \\
\left( \pm 0.003 \mathrm{mg} \mathrm{P}-\mathrm{PO}^{4} / \mathrm{L}\right)\end{array}$ & $\begin{array}{l}0.0 \text { to } 2.5 \mathrm{mg} \mathrm{P}_{-}-\mathrm{PO}_{4}{ }^{3-} / \mathrm{L} \\
0.0 \text { to } 0.82 \mathrm{mg} \mathrm{P}_{-} \mathrm{PO}_{4} / \mathrm{L}\end{array}$ \\
\hline
\end{tabular}

${ }^{\dagger}$ Corrects for temperature for samples between -2 and $35^{\circ} \mathrm{C}$

* Scale adjusts automatically according to measurement

*From the respective measurement scale

${ }^{a}$ Corrects for temperature for samples between 0 and $50{ }^{\circ} \mathrm{C}$ and for salinity between 0.0 and $50.0 \%$ 